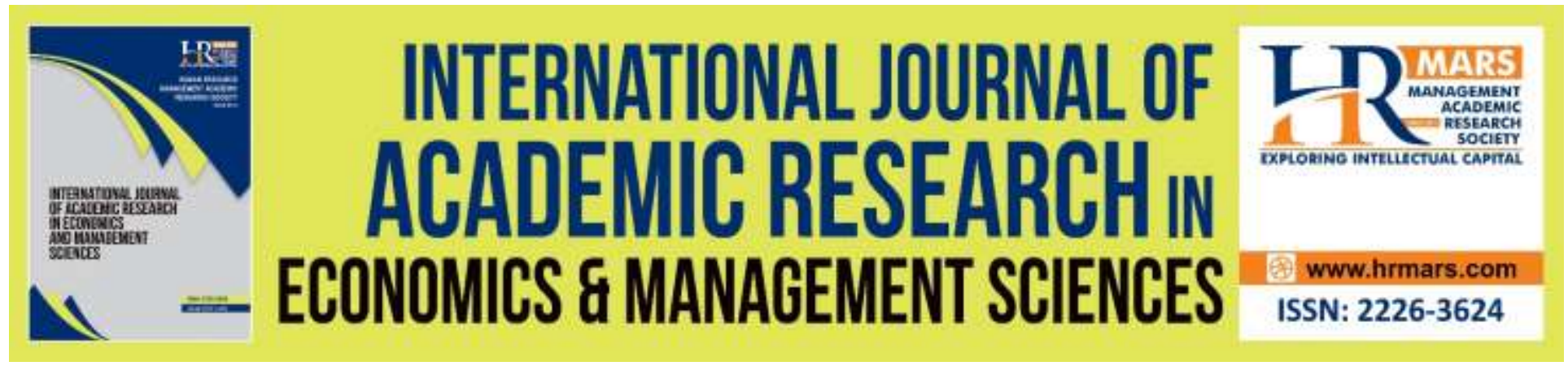

\title{
Service Quality of Private Nurseries in Kuching City: Perception of Parents
}

Ho Chui Tchin, Siti Aisyah Ya'kob and Mohd Uzairi Ahmad Hajazi

To Link this Article: http://dx.doi.org/10.6007/IJAREMS/v8-i3/6655

DOI: $10.6007 /$ IJAREMS/v8-i3/6655

Received: 23 September 2019, Revised: 21 October 2019, Accepted: 10 November 2019

Published Online: 28 November 2019

In-Text Citation: (Tchin, Ya'kob, \& Hajazi, 2019)

To Cite this Article: Tchin, H. C., Ya'kob, S. A., \& Hajazi, M. U. A. (2019). Service Quality of Private Nurseris in Kuching City: Perception of Parents. International Journal of Academic Research in Economics and Management Sciences, 8(3), 421-438.

Copyright: (c) 2019 The Author(s)

Published by Human Resource Management Academic Research Society (www.hrmars.com)

This article is published under the Creative Commons Attribution (CC BY 4.0) license. Anyone may reproduce, distribute, translate and create derivative works of this article (for both commercial and non-commercial purposes), subject to full attribution to the original publication and authors. The full terms of this license may be seen

at: http://creativecommons.org/licences/by/4.0/legalcode

Vol. 8, No. 3, 2019, Pg. 421 - 438

http://hrmars.com/index.php/pages/detail/IJAREMS

JOURNAL HOMEPAGE

Full Terms \& Conditions of access and use can be found at http://hrmars.com/index.php/pages/detail/publication-ethics 


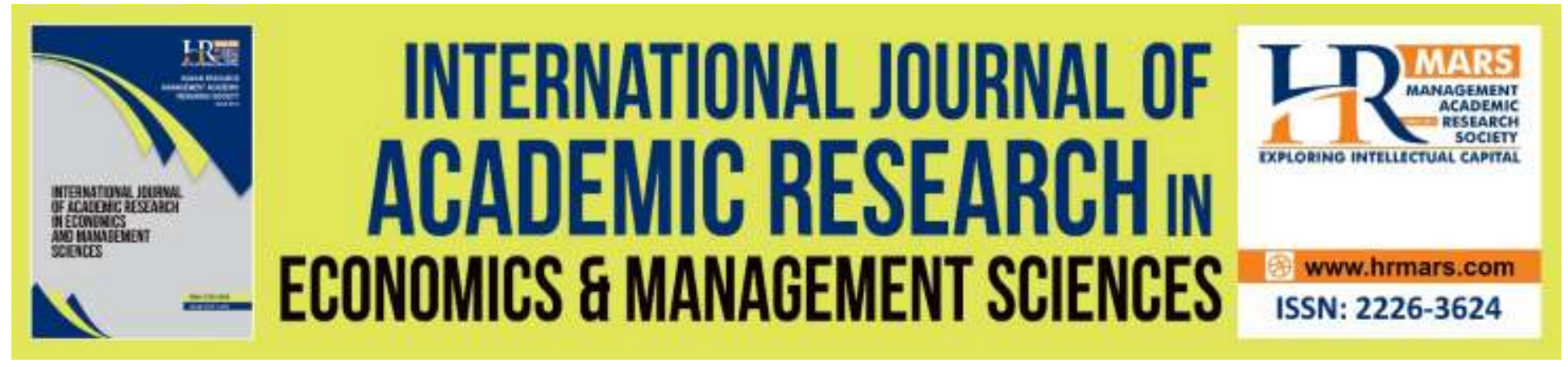

\title{
Service Quality of Private Nurseries in Kuching City: Perception of Parents
}

\author{
Ho Chui Tchin, Siti Aisyah Ya'kob and Mohd Uzairi Ahmad Hajazi \\ Faculty of Economics and Business, Universiti Malaysia Sarawak, Malaysia. \\ Email: ysaisyah@unimas.my
}

\begin{abstract}
The spring-up of private nurseries in this era has triggered the trend for working parents to send their kids to private nurseries. This phenomenon has led to an increasing interest in assessing the service quality provided by nurseries. Therefore, this study aims to examine the relationship between service quality and parents' satisfaction towards the private nursery. A total of 399 samples were obtained in this study through the distribution of questionnaires in Kuching city, Sarawak. Pearson's correlation is used to examine the direction of the relationship between independent variables (tangibles, reliability, responsiveness, assurance and empathy) and dependent variable (parent satisfaction); while multiple regression analysis had also been used to determine the most dominant dimension that contributes to parents' satisfaction. The findings of this study revealed that the majority of the respondents have a high level of satisfaction towards the service offered by the private nursery in Kuching. Meanwhile, there is a significant relationship between SERVQUAL dimensions and parents' satisfaction except for the reliability dimension. In addition, findings also found out that the tangibility of the service is the most dominant dimension in enhancing parent satisfaction. The results suggest the service providers in nursery place should emphasize more on physical facilities of the nursery as well as maintaining hygiene to leverage parents' satisfaction.
\end{abstract}

Keywords: Service Quality, Early Childhood, Parents Satisfaction, Servqual

\section{Introduction}

Early Childcare and Education (ECCE) has stood a spot in the precedence segments of the Ministry of Education. The unexploited early child care market for children aged between one week to four years has been studied. This will help to provide useful insights to serve the increasing demand for improved quality and experience in early education. Education being categorized as one of the predominant service industries in which mankind acclaims education as a powerful tool for civilization especially early education due to its great impact on children's growth. Aside from monitoring the quality of education system in terms of the curriculum, the service quality of education providers ought to be kept in pace with the standard of our education system to provide satisfaction to the users namely the parents and also the children. 
INTERNATIONAL JOURNAL OF ACADEMIC RESEARCH ECONOMICS AND MANAGEMENT SCIENCES Vol. 8, No. 3, 2019, E-ISSN: 2226-3624 @ 2019 HRMARS

There are different types of pre-school institutions where they can be differentiated through the medium of instruction given to children, religious orientation, curriculum approaches or the origin of the institutions. The various types of pre-school are illustrated in Table 1 below.

Table 1: Types of Pre-school in Malaysia

\begin{tabular}{ll}
\hline Types of Pre-school & Agency/ Department/Example \\
\hline $\begin{array}{l}\text { Pre-school attached to national } \\
\text { primary school }\end{array}$ & Ministry of Education \\
KEMAS & Ministry of Rural Development \\
Tadika Perpaduan & Ministry of National Integrity \\
KAFA & State Islamic Religious Department \\
International Schools & Tenby International School \\
& Lodge International School \\
NGO pre-schools & ABIM \\
Private Pre-schools & Montessori, SmartReader \\
Religious based pre-schools & Tahfiz Al-Qur'an, church-based \\
& kindergarten \\
Language-based & Chinese medium, English medium \\
Politically affiliated pre-schools & PASTI by Islamic Party of Malaysia \\
& (PAS) \\
& Chinese pre-schools by the Malaysian \\
& Chinese Association (MCA) \\
\hline
\end{tabular}

Source: Mustafa, Yunus, and Azman (2014)

Preschool and childcare play a vital role in preparing children to enter primary school in the future. Early child care provides the children with their first fundamental formal education. Apart from equipping the children to enter the first year of primary school, childcare also accommodates early instillation of moral values as well as social intelligence among young children. Findings from previous studies show that good quality child care centers bring about significant effects on children's growth and development (Doherty, Forer, Lero, Goelman, \& LaGrange, 2006; Iram \& Butt, 2004; Liu, Yeung, \& Farmer, 2001).

Nevertheless, although service quality, in general, has gained attention in relation to retaining and satisfying the customer in the service industry (Spreng \& MacKoy, 1996; Anghel, Anghelache, Dumitrescu, Burea, Stoica, 2018), there is still a lack of study concerning service quality of child care and its relation towards parent satisfaction in Malaysia. This is in spite of the fact that most families in Malaysia are becoming more concerned and selective when choosing child care, due to i) its vital role in children's development; ii) recent issues concerning child care service provider in Malaysia such as child abuse, unregistered service provider and safety. Therefore, this research aims to study the relationship between service quality and parents' satisfaction in child care service providers in Malaysia.

The researchers want to make a contribution in the following area, firstly, to develop an understanding of the relationship between service quality and parents' satisfaction towards child care service providers in Malaysia, using providers in Kuching city, Sarawak as a case study. 
Although similar research might have been conducted elsewhere, however, the findings may be different from this research. Therefore, the context, or the choice of location - in this case, is Kuching, Malaysia - will provide significant contributions to existing knowledge. Secondly, this study adopted SERVQUAL dimensions - tangibles, reliability, responsiveness, assurance and empathy - to measure service quality of child care service. Using these five dimensions will add a different perspective on how service quality of child care service will affect parents' satisfaction as other researches might use different variables in measuring service quality.

The next section presents the review of theoretical studies as well as the discussion on the past studies; follows by the data and methodology section. The subsequent section presents the findings of this study followed by the discussion of the results.

\section{Literature Review}

McNaughton (1994) suggested four dominant reasons to collect information on parents' satisfaction. The first reason identified was that parents are responsible and have control over the child's development therefore they will place their children's future as a top priority when making decisions. Another reason for this data collection is that it is beneficial as a reference to develop better services. The sources of evaluation which include feedback from parents mean a lot especially to policymakers and program planners in early intervention service (Upshur, 1991). Thirdly, parent's involvement in providing evaluation might contribute to more participation from the parent in programs (Bailey, 1987). Some parents may be demotivated to participate in the particular activity when they find it not relevant while some may have the motivation to join yet lack of time and other issues arisen. Lastly, customer satisfaction data is useful to persuade other institutions or organizations especially funding agencies on the value of the programs (Scheirer, 1978; Kassim, Baharuddin, Ishak, Ariff, \& Buyong, 2018).

Friedman, Bobrowski and Markow (2007) found that there are three factors contribute towards parents' satisfaction. One of the factors was that parents receiving pleasant information regarding the children's performance and involvement in school from teachers. Other than that, school resources and the leadership portrayed in the good management of the school budget lead to parents' satisfaction with the school. Virtanen and Runtti (2015) suggested that enjoyment of child in school, teachers' personality, teaching methods used and affirmative experience by home-school collaboration. Overall in that study, parents were pleased with the quality of education and care. On the contrary, Gibbons and Silva (2011) proposed that children's learning environment and test-score based measures were the dominant influence on parental satisfaction.

Jonsdottir, Bjornsdottir, and Bæck (2017) emphasized the child's well-being and development have the most influence on parents' satisfaction and dissatisfaction. Parents and children both experience disappointment when the school being irresponsible and failed to entertain the child's need which leads to dissatisfaction. In addition to that, the ability of parents to influence future vision and decisions of school is found to influence the parent's satisfactory level. Parents who feel this way have a higher satisfaction level towards the school. There are many factors contributing to parent satisfaction yet insufficient literature on service quality founded as a determinant of parents' satisfaction. Hence this study examines the relationship between service quality and parents' satisfaction in the early education and care industry. 
Delivering top-quality service to meet customer satisfaction is the key enables the firm to be sustainable in the competitive environment (Arokiasamy \& Tat, 2014). In most countries, the services industry makes a huge contribution to the country's economic activity (Guesalaga \& Pitta, 2014). Service quality is a mixture of service and quality, services are intangible and have been described as performances or efforts. According to Gronroos (1984), high consumer involvement is required during the consumption process. In short, services are not solely interaction between customers and employees or goods or system provided by service providers but a series of activities of intangible nature (Gronroos, 1984).

There are five dimensions of service quality namely tangibles, empathy, responsiveness, reliability, and assurance services as characteristics of service quality encounter (Parasuraman, Zeithaml \& Berry, 1988). Rust and Oliver (1994) mentioned that management of service quality involving the delivery of service, service environment and interaction between customer and employee.

\section{Tangibles}

Tangibles are identified as the physical appearance of the organization including facilities, equipment as well as the appearance of personnel (Parasuraman et al., 1985). This dimension is commonly used to relate the physical properties of the service providers, the tools utilized to provide service and also the appearance of the employees. Researchers will have various interpretations of the context of dimensions of service quality in view of the nature of the firm's industry. SERVQUAL scale being regarded as one of the commonly employed measurements in assessing service quality not only in marketing, retailing and also in other disciplines such as education. Research done by Kim (2014) on the quality analysis of child care services by applying the SERVQUAL model portrayed that two indexes of tangibles have relatively high expectations. However, the satisfaction level is low if compare with other indexes. The tangibles of the child care center are evaluated based on whether the center is hygienically maintained, well equipped with physical facilities and safety equipment such as a safety bar that meets customers' satisfaction. The researcher suggested that the improvement of service quality can be done on the cleanliness of physical facilities such as indoor play equipment, teaching aids, corridor, entrance and playroom to achieve a higher satisfaction level of users. Therefore, the following alternatives hypotheses between the dependent variable and independent variables have been developed:

$\mathrm{H}_{1}$ : There is a positive and significant relationship between tangibles and parents' satisfaction towards the private nursery.

\section{Reliability}

According to Parasuraman et al. (1985), reliability is defined as a competency of the firm or service provider to constantly perform committed service with high efficiency and error-free. In addition to that, the firm is able to perform the right service at all times. Parasuraman discovered that customers constantly categorized the dimensions of service quality into similar general categories. The core service dimension that found to have the most influence on quality is the reliability of service, followed by assurances, tangibility, service responsiveness and lastly empathy for the customer. This order has been ranked from the most important to the least important (MANG'ELI, 2013). Reliability is one of the dimensions of service quality that has been 
discovered as the core dimension to most customers while tangibility was ranked as least important (Berry, Zeithaml, \& Parasuraman, 1990). This finding has been supported by Bigne, Martinez, Miquel and Andreu (2003) in which reliability dimension weight the most in the studies conducted on services performed by travel agencies.

In the study by Kim (2014), there were respectively two indexes of tangibles and reliability accounted for high expectations yet low satisfactory level when comparing with the rest of the indexes indicating that further improvements are needed. Service reliability in the context of child care services is examined through the systematic services provided, daily bookkeeping, and quality of the food as well as being reliable in performing services. For the sake of increase, the level of satisfaction, the child care center was recommended to improve on meal service and skills responding to emergency situations. Thus, the following hypothesis is proposed:

\section{$\mathrm{H}_{2}$ : There is a positive and significant relationship between reliability and parents' satisfaction towards the private nursery.}

\section{Responsiveness}

A study in the Canadian banking sector revealed that responsiveness along with empathy were the predominant contributors to customer satisfaction, perceived service quality, loyalty and recommendation (Ladhari, 2009). It is because these dimensions reflect the interaction between employees and customers. Items measured for the responsiveness dimension are on the willingness of employees to respond to customers' needs and speedy service provided.

Responsiveness is defined as the willingness or the readiness of employees to provide prompt service. This measure emphasizes providing efficient customer support and being devoted to dealing with requests from customers (Parasuraman et al., 1985). Responsiveness in the context of child care services refers to the willingness of the center to accommodate children's and parents' demands as well as portraying a proactive attitude in servicing both children and parents (Kim, 2014). Findings from the study mentioned that the index of teachers' attitudes in educating children received 4.47 points for expectation level and 4.20 points for satisfaction level which is considered high compared to their average values. Improvement of service quality of this index is in need as the expectation level for it is remarkably high. Therefore the hypothesis for the relationship between responsiveness and parents' satisfaction in the private nursery is proposed: $\mathrm{H}_{3}$ : There is a positive and significant relationship between responsiveness and parents' satisfaction towards the private nursery.

\section{Assurance}

Assurance inspires trust and confidence in customers. It is based on employees' courtesy as well as knowledge to provide information to customers which lead to security and pleasing services delivered to customers (Parasuraman et al., 1985). Credibility, staff competence, probity and confidentiality and security are among the measure taken into consideration to evaluate the assurance dimension of the firm. A study by Arasli, Turan Katircioglu and Mehtap-Smadi (2005) found that the assurance dimension influenced customer satisfaction and overall satisfaction the most in the Cyprus banking industry. In contrast, there was a substantial contrast among expected and saw administration in the empathy dimension. The assurance dimension is judged based on the inspiring confidence depicted by employees, secure transactions with the bank, courteous and knowledgeable employees in the bank to answer customers' questions. 
Kim (2014) measured the index of assurance in the child care industry based on knowledgeable and courteous teachers or caregivers that are able to stimulate trust and confidence. In this study, having an appropriate attitude to take care of children and portraying an essential character that meets the requirement as an early education teacher is among the indexes expected to achieve customer satisfaction. Therefore the hypothesis is posited as:

$\mathbf{H}_{4}$ : There is a positive and significant relationship between assurance and parents' satisfaction towards the private nursery.

\section{Empathy}

Empathy is instilled when the firm provides affectionate, unique attention to the customers and understands the needs (Parasuraman et al., 1985). Wang, Lo and Yang (2004) modified the SERVQUAL model to include the convenience of the operating hours and location under the dimension of assurance to suit the study on the telecommunication industry. Suki (2013) conducted a study to investigate the correlation of service quality in the hotel industry towards tourists' satisfaction. Data obtained from 200 respondents with previous experience of tourism goods and services in the Federal Territory of Labuan showed that service quality substantially corresponds to tourists' satisfaction. In this study, empathy was the most predominant predictor of tourists' satisfaction among the five dimensions of SERVQUAL model. A study carried out by Ladhari (2009) in the Canadian banking sector exhibited that empathy together with responsiveness were the significant dimensions that lead to customer satisfaction. Empathy is being evaluated through the pleasant and courteous service provided by the bank employees. Under the context of child care service quality, empathy is measured through the caring and personalized attention given to parents and children by service providers (Kim, 2014). The results of this study discovered that parents expected their children to have sufficient interaction with teachers to satisfy the children. The expectation level and satisfaction level received 4.21 and 4.02 respectively under the five-point scale. Another index on teachers' ability to recognize parents' and children's characteristics scored higher points for expectation level indicating low urgency for improvement in empathy. Nevertheless, it is hypothesized that:

$\mathbf{H}_{5}$ : There is a positive and significant relationship between empathy and parents' satisfaction towards the private nursery.

\section{Methodology}

The target population of this research study is parents with young children in their families in Sarawak while the accessible population is the parents with young children in Kuching city. According to the statistics released in the official portal of Sarawak Government, the total population of Kuching city accounted for 684,900 based on the projection in the year of 2017. In this research, a non-probability sampling technique is implemented. Convenience sampling is among the non-probability techniques being applied in this study. Snowball sampling will also be used to generate the sample of study through recommendations made among people sharing or knowing others who met the characteristics required by the research (Biernacki \& Waldorf, 1981). The initial respondents are chosen based on probability methods and they later provide information about additional respondents to yield more study samples (Zikmund et al., 2013). The sample size of 400 with a sampling error of 0.05 was calculated using Slovin's formula. 
The questionnaire was designed using items that have been tested previously by Kim (2014) and Olorunniwo, Hsu and Udo (2006). The questionnaire comprises of three sections. The first section measured the respondents' background information while the other two sections were measured using a five-point Likert scale. Respondents are required to rate based on the 5-point Likert scale range to express their level of agreement which constitutes, 1 as strongly disagree of the statement, 2 as disagree, 3 as neutral, 4 as agree of the statement and 5 as strongly agree of the statement. In this study, the instrument used to gather information from the targeted sample is a self-administered questionnaire. In this self-administered survey, there is no interviewer involved in the data collecting process. Respondents are responsible to read and answer the questions (Zikmund et al., 2013). This self-administered questionnaire will be distributed in printed and electronic form through the advancement of technology.

\section{Empirical Results}

\section{Respondent's Profile}

All the respondents in this study were parents who sent their kids to the private nurseries in Kuching. In this study, female respondents make up the largest portion among the respondents with a total of $297(74.4 \%)$ while the male respondents stood at 102 (25.6\%). Most of them aged $31-40$ years old $(50.1 \%)$. It showed that the majority of the respondents have up to degree level qualification (46.9\%) and $60.2 \%$ of them working in the private sector. From the analysis, it can be observed that the majority of the respondents $(30.1 \%)$ earned a household income between RM3,001-RM4,500. From the total respondents, $44.1 \%$ of them have two children in their family which are sent to the nursery and most of them spend around RM401- RM600 for the nursery fees. The most chosen type of care is a full-day service (77.2\%). The respondents' profile is presented in Table 2.

Table 2: Respondents' Profile

\begin{tabular}{llll}
\hline Demographic Variable & Category & Frequency & $\begin{array}{l}\text { Percentage } \\
\text { (\%) }\end{array}$ \\
\hline Gender & Male & 102 & 25.6 \\
& Female & 297 & 74.4 \\
Age & 20 and below & 5 & 1.3 \\
& $21-30$ & 124 & 31.1 \\
& $31-40$ & 200 & 50.1 \\
& $41-50$ & 64 & 16.0 \\
Education & Above 50 & 6 & 1.5 \\
& Certificate & 70 & 17.5 \\
& Diploma & 119 & 29.8 \\
& Degree & 187 & 46.9 \\
Occupation & Postgraduate & 23 & 5.8 \\
& Private sector & 240 & 60.2
\end{tabular}


INTERNATIONAL JOURNAL OF ACADEMIC RESEARCH ECONOMICS AND MANAGEMENT SCIENCES Vol. 8, No. 3, 2019, E-ISSN: 2226-3624 @ 2019 HRMARS

\begin{tabular}{|c|c|c|c|}
\hline Demographic Variable & Category & Frequency & $\begin{array}{l}\text { Percentage } \\
(\%)\end{array}$ \\
\hline & Government sector & 111 & 27.8 \\
\hline & Retirees & 6 & 1.5 \\
\hline & Unemployed & 42 & 10.5 \\
\hline \multirow[t]{5}{*}{ Household Income } & RM1,500 and below & 37 & 9.3 \\
\hline & RM1,501- RM3,000 & 89 & 22.3 \\
\hline & RM3,001- RM4,500 & 120 & 30.1 \\
\hline & RM4,501- RM6,000 & 74 & 18.5 \\
\hline & RM6,001 and above & 79 & 19.8 \\
\hline \multirow[t]{5}{*}{ Number of children } & One & 149 & 37.3 \\
\hline & Two & 176 & 44.1 \\
\hline & Three & 58 & 14.5 \\
\hline & Four & 13 & 3.3 \\
\hline & Five and more & 3 & 0.8 \\
\hline \multirow{3}{*}{$\begin{array}{l}\text { Number of children sent to } \\
\text { a nursery }\end{array}$} & One & 286 & 71.7 \\
\hline & Two & 105 & 26.3 \\
\hline & Three & 8 & 2.0 \\
\hline \multirow[t]{5}{*}{ Nursery fee } & RM200-RM400 & 90 & 22.6 \\
\hline & RM401-RM600 & 133 & 33.3 \\
\hline & RM601-RM800 & 129 & 32.3 \\
\hline & RM801-RM1000 & 40 & 10.0 \\
\hline & RM1,001 and above & 7 & 1.8 \\
\hline \multirow[t]{2}{*}{ Type of care } & Half-day & 91 & 22.8 \\
\hline & Full-day & 308 & 77.2 \\
\hline
\end{tabular}

\section{Factor Analysis}

The principal components analysis is conducted to identify a new set of variables that are statistically significant for this study. This analysis is done to suit the samples which are the working parents and current condition. The imperative concern of investigating the factor analysis is to retain the Barlett's test of Sphericity significant value less than 0.05 (Cohen, Manion, \& Morrison, 2007) and to select the items with Kaiser-Meyer-Olkin (KMO) sampling adequacy test close to 1.0. This study suppresses the absolute value of less than 0.3999 (Coakes and Ong, 2011).

The Keiser-Meyer-Olkin (KMO) and Barlett's test of Sphericity are performed to confirm if factor analysis could be done or not (Tabachnick \& Fidell, 2001). Following a rule of thumb, the factor analysis selects the items with KMO close to 1.0 (Cohen et al., 2007). Furthermore, Barlett's Test is applied to "test the equality of variance" which close to 0.00 (Zainuddin, 2012). 
The initial KMO is 0.941 which indicates the sample is adequate for factor analysis. Next, Barlett's test is statistically significant (Chi-Square $=7416.161, p<0.001$ ). As the sampling adequacy is proven, the factor analysis is conducted.

The factors loadings of all the variables are presented in Table 3 for the supply chain linkages constructs.

Table 3: Rotated Component Matrix for Service Quality

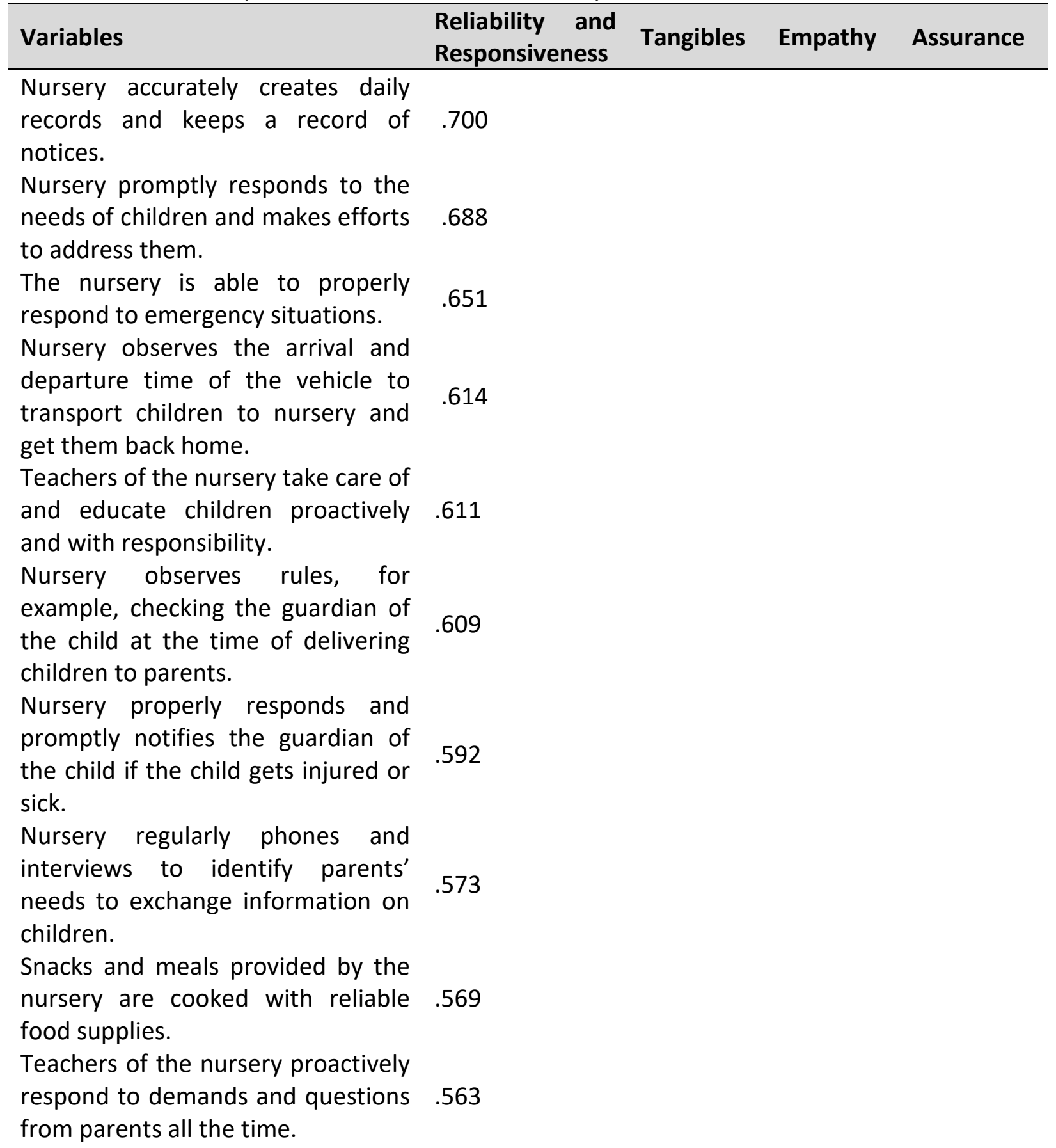




\begin{tabular}{|c|c|c|c|c|}
\hline Variables & $\begin{array}{l}\text { Reliability and } \\
\text { Responsiveness }\end{array}$ & Tangibles & Empathy & Assurance \\
\hline $\begin{array}{l}\text { Nursery observes operation hours } \\
\text { and services are smoothly offered } \\
\text { within the prescribed operation } \\
\text { hours. }\end{array}$ & .559 & & & \\
\hline $\begin{array}{l}\text { The restroom, washroom, kitchen } \\
\text { and feeding room of this nursery are } \\
\text { hygienically maintained. }\end{array}$ & & .793 & & \\
\hline $\begin{array}{l}\text { The daycare room (classroom), } \\
\text { entrance, corridor, playroom and } \\
\text { auditorium of this nursery are } \\
\text { hygienically maintained. }\end{array}$ & & .785 & & \\
\hline $\begin{array}{l}\text { The nursery is properly equipped } \\
\text { with safety equipment such as non- } \\
\text { slip mats, etc. in the restroom and } \\
\text { washroom. }\end{array}$ & & .706 & & \\
\hline $\begin{array}{l}\text { The nursery is well equipped with } \\
\text { play equipment (facilities) and } \\
\text { teaching aids within doors. }\end{array}$ & & .673 & & \\
\hline $\begin{array}{l}\text { The nursery is properly equipped } \\
\text { with safety equipment such as a } \\
\text { safety bar in indoor stairways and } \\
\text { indoor and outdoor playground } \\
\text { facilities. }\end{array}$ & & .626 & & \\
\hline $\begin{array}{l}\text { The nursery is well equipped with } \\
\text { outdoor playground facilities. }\end{array}$ & & .614 & & \\
\hline $\begin{array}{l}\text { The nursery is well equipped with a } \\
\text { daycare room. }\end{array}$ & & .533 & & \\
\hline $\begin{array}{l}\text { Children using the nursery } \\
\text { sufficiently interact with teachers } \\
\text { and children are satisfied therewith. } \\
\text { E }\end{array}$ & & & .815 & \\
\hline $\begin{array}{l}\text { Teachers of the nursery pay } \\
\text { sufficient attention to each and } \\
\text { every child. }\end{array}$ & & & .782 & \\
\hline $\begin{array}{l}\text { Teachers of the nursery genuinely } \\
\text { consider the growth and } \\
\text { development of children. }\end{array}$ & & & .769 & \\
\hline $\begin{array}{l}\text { Teachers of the nursery well identify } \\
\text { individual disposition and } \\
\text { characteristics of parents and } \\
\text { children. }\end{array}$ & & & .754 & \\
\hline
\end{tabular}


INTERNATIONAL JOURNAL OF ACADEMIC RESEARCH ECONOMICS AND MANAGEMENT SCIENCES Vol. 8, No. 3, 2019, E-ISSN: 2226-3624 @ 2019 HRMARS

\begin{tabular}{|c|c|c|c|c|}
\hline Variables & $\begin{array}{l}\text { Reliability and } \\
\text { Responsiveness }\end{array}$ & Tangibles & Empathy & Assurance \\
\hline $\begin{array}{l}\text { Teachers of the nursery are } \\
\text { trustable and reliable in the usage of } \\
\text { the facility. }\end{array}$ & & & & .808 \\
\hline $\begin{array}{l}\text { Teachers of the nursery have a } \\
\text { proper attitude to deal with children } \\
\text { with care and love all the time. }\end{array}$ & & & & .727 \\
\hline $\begin{array}{l}\text { Teachers of the nursery have } \\
\text { character and refinement suitable } \\
\text { and required for child care teachers } \\
\text { and kindergarten teachers. }\end{array}$ & & & & .724 \\
\hline Eigenvalue & 12.760 & 1.729 & 1.178 & 1.109 \\
\hline$\%$ of Variance & 51.042 & 6.917 & 4.711 & 4.437 \\
\hline Cumulative $\%$ of Variance & 51.042 & 57.959 & 62.670 & 67.107 \\
\hline
\end{tabular}

Extraction Method: Principal Component Analysis.

Rotation Method: Varimax with Kaiser Normalization.

a. Rotation converged in 7 iterations.

After performing the factor analysis, four factors are extracted. The commonalities less than 0.3999 are deleted and re-run until no commonalities below 0.3999 are obtained. Referring to Table 3, four factors are extracted after seven iterations from 25 variables. Each extracted factor has Eigenvalue over 1 . All for the extracted factor accounted for $67.107 \%$ of the variance. In detail, Factor 1 is made up of 11 variables; Factor 2 is made up of seven variables; Factor 3 is made up of four variables, and Factor 4 is made up of three variables respectively. They are named as reliability and responsiveness, tangibles, empathy, and assurance. Two variables were removed in this analysis - i.e. "Nursery provides services according to annual, monthly and weekly plans." and "Teachers of the nursery have sufficient professional knowledge about child care and education according to development stages of children."

\section{Reliability}

Reliability analysis is useful to assess how free the variables are from random error (Pallant, 2013). The reliability analysis has been used to test the reliability as well as the consistency of each item in the variable of this study. The results have been illustrated in Table 4.

Table 4: Results of Reliability Analysis

\begin{tabular}{lll}
\hline Variables & Number of items & Cronbach's Alpha \\
\hline Reliability and responsiveness & 11 & 0.924 \\
Tangibles & 7 & 0.904 \\
Empathy & 4 & 0.906 \\
Assurance & 3 & 0.863 \\
Parents Satisfaction & 4 & 0.915 \\
\hline
\end{tabular}


INTERNATIONAL JOURNAL OF ACADEMIC RESEARCH ECONOMICS AND MANAGEMENT SCIENCES Vol. 8, No. 3, 2019, E-ISSN: 2226-3624 @ 2019 HRMARS

\section{Correlations}

Based on the correlation result in Table 5, it showed that all the independent variables - i.e. reliability and responsiveness, tangibles, empathy, and assurance were significantly correlated with the dependent variable - i.e. parent satisfaction at 0.000 significance level. The strength of the correlation coefficient referred to the rule of thumb provided by Hair, Barbin and Anderson (2019). It indicates that the coefficient range from 0.81 to 1.00 is very strong, 0.61 to 0.80 is strong, 0.41 to 0.60 is moderate, 0.21 to 0.40 is weak with low correlation, and 0.00 to 0.20 is very weak to no relationship at all. The correlation presents a strong positive correlation between tangibles with parents' satisfaction $(r=0.722, p=0.000)$, reliability and responsiveness with parents' satisfaction $(r=0.721, p=0.000)$, empathy with parents' satisfaction $(r=0.638, p=$ $0.000)$, and lastly assurance with parents' satisfaction $(r=0.604, p=0.000)$.

Table 5: Correlations

\begin{tabular}{|c|c|c|c|c|c|c|}
\hline & & Tangible & $\begin{array}{l}\text { Reliability and } \\
\text { responsiveness }\end{array}$ & Empathy & Assurance & $\begin{array}{l}\text { Parents } \\
\text { Satisfaction }\end{array}$ \\
\hline \multirow[t]{3}{*}{ Tangibles } & $\begin{array}{l}\text { Pearson } \\
\text { Correlation }\end{array}$ & 1 & $.785^{* *}$ & $.609^{* *}$ & $.602^{* *}$ & $.722^{* *}$ \\
\hline & $\begin{array}{l}\text { Sig. } \\
\text { tailed) }\end{array}$ & & .000 & .000 & .000 & .000 \\
\hline & $\mathrm{N}$ & 399 & 399 & 399 & 399 & 399 \\
\hline \multirow[t]{3}{*}{$\begin{array}{l}\text { Reliability and } \\
\text { responsiveness }\end{array}$} & $\begin{array}{l}\text { Pearson } \\
\text { Correlation }\end{array}$ & $.785^{* *}$ & 1 & $.667^{* *}$ & $.653^{* *}$ & $.721^{* *}$ \\
\hline & $\begin{array}{l}\text { Sig. } \\
\text { tailed) }\end{array}$ & .000 & & .000 & .000 & .000 \\
\hline & $\mathrm{N}$ & 399 & 399 & 399 & 399 & 399 \\
\hline \multirow[t]{3}{*}{ Empathy } & $\begin{array}{l}\text { Pearson } \\
\text { Correlation }\end{array}$ & $.609^{* *}$ & $.667^{* *}$ & 1 & $.627^{* *}$ & $.638^{* *}$ \\
\hline & $\begin{array}{l}\text { Sig. } \\
\text { tailed) }\end{array}$ & .000 & .000 & & .000 & .000 \\
\hline & $\mathrm{N}$ & 399 & 399 & 399 & 399 & 399 \\
\hline \multirow[t]{3}{*}{ Assurance } & $\begin{array}{l}\text { Pearson } \\
\text { Correlation }\end{array}$ & $.602^{* *}$ & $.653^{* *}$ & $.627^{* *}$ & 1 & $.604^{* *}$ \\
\hline & $\begin{array}{l}\text { Sig. } \\
\text { tailed) }\end{array}$ & .000 & .000 & .000 & & .000 \\
\hline & $\mathrm{N}$ & 399 & 399 & 399 & 399 & 399 \\
\hline \multirow{4}{*}{$\begin{array}{l}\text { Parents } \\
\text { Satisfaction }\end{array}$} & Pearson & $.722^{* *}$ & $.721^{* *}$ & $.638^{* *}$ & $.604^{* *}$ & 1 \\
\hline & Correlation & & & & & \\
\hline & $\begin{array}{l}\text { Sig. } \\
\text { tailed) }\end{array}$ & .000 & .000 & .000 & .000 & \\
\hline & $\mathrm{N}$ & 399 & 399 & 399 & 399 & 399 \\
\hline
\end{tabular}

**. Correlation is significant at the 0.01 level (1-tailed). 
INTERNATIONAL JOURNAL OF ACADEMIC RESEARCH ECONOMICS AND MANAGEMENT SCIENCES Vol. 8, No. 3, 2019, E-ISSN: 2226-3624 @ 2019 HRMARS

\section{Multiple Regression}

Multiple regression analysis provides the information about the dimensions of service quality that influence parents' satisfaction. The results in Table 6 explains that tangibles (sig. $=0.000, p$ $<0.05$ ), reliability and responsiveness (sig. $=0.000, p<0.05)$, empathy (sig. $=0.000, p<0.05$ ), and assurance (sig. $=0.009, p<0.05$ ) are significant in observing the influence of service quality on parents satisfaction. The beta weight indicates that tangibles $(\beta=0.335)$ is perceived to have the most influential dimension on the parents satisfaction, while reliability and responsiveness $(\beta=$ $0.255)$ as well as empathy $(\beta=0.190)$ have a lesser influence on parents satisfaction. Lastly, assurance $(\beta=0.116)$ is observed to have the least impact on parents satisfaction.

Table 6: Results of Multiple Regression Analysis

\begin{tabular}{|c|c|c|c|c|c|c|c|}
\hline \multirow{2}{*}{\multicolumn{3}{|c|}{ Model }} & \multicolumn{2}{|c|}{$\begin{array}{l}\text { Unstandardized } \\
\text { Coefficients }\end{array}$} & \multirow{2}{*}{$\begin{array}{l}\text { Standardized } \\
\text { Coefficients } \\
\text { Beta }\end{array}$} & \multirow[b]{2}{*}{$\mathbf{t}$} & \multirow[b]{2}{*}{ Sig. } \\
\hline & & & B & Std. Error & & & \\
\hline \multirow[t]{5}{*}{1} & (Constant) & & .423 & .159 & & 2.660 & .008 \\
\hline & Tangibles & & .353 & .054 & .335 & 6.487 & .000 \\
\hline & $\begin{array}{l}\text { Reliability } \\
\text { responsiveness }\end{array}$ & and & .286 & .063 & .255 & 4.540 & .000 \\
\hline & Empathy & & .178 & .042 & .190 & 4.246 & .000 \\
\hline & Assurance & & .118 & .045 & .116 & 2.619 & .009 \\
\hline
\end{tabular}

a. Dependent Variable: Parents Satisfaction

Table 7 presents coefficient ( $R$ Square) is 0.617 which means that $61.70 \%$ of the variance in parents' satisfaction can be explained from the four independent variables named as tangibles, reliability and responsiveness, empathy, and assurance.

Table 7: Model Summary

\begin{tabular}{ll|lll}
\hline Model & $\mathbf{R}$ & R Square & Adjusted R Square & $\begin{array}{l}\text { Std. Error of the } \\
\text { Estimate }\end{array}$ \\
\hline 1 & $.786^{\text {a }}$ & .617 & .614 & .41177 \\
\hline
\end{tabular}

a. Predictors: (Constant), Assurance, Tangibles, Empathy, Reliability and responsiveness

b. Dependent Variable: Parents Satisfaction

The ANOVA result in Table 8 reveals that the model is statistically significant (sig. $=0.000$, $p<0.05$ ) with F-value 158.981 . The probability value of 0.000 indicates that out of 1000 , there is no chance that the correlation coefficient is zero.

Table 8: ANOVA Result

\begin{tabular}{lllllll}
\hline Model & & Sum of Squares & df & Mean Square & F & Sig. \\
\hline 1 & Regression & 107.823 & 4 & 26.956 & 158.981 & $.000^{\mathrm{b}}$ \\
& Residual & 66.804 & 394 & .170 & & \\
& Total & 174.627 & 398 & & & \\
\hline
\end{tabular}

a. Dependent Variable: Parents Satisfaction

b. Predictors: (Constant), Assurance, Tangible, Empathy, Reliability and responsiveness 
INTERNATIONAL JOURNAL OF ACADEMIC RESEARCH ECONOMICS AND MANAGEMENT SCIENCES Vol. 8, No. 3, 2019, E-ISSN: 2226-3624 @ 2019 HRMARS

\section{Hypothesis Testing}

Based on the results, it can be concluded that three out of the five hypotheses proposed were supported (Table 9).

Table 9: Summary of Hypothesis

\begin{tabular}{l} 
Hypothesis \\
\hline $\mathbf{H}_{\mathbf{1}}$ : There is a positive and significant relationship between \\
tangibles and parents' satisfaction towards the private Supported \\
nursery. \\
$\mathbf{H}_{\mathbf{2}}$ : There is a positive and significant relationship between \\
reliability and parents' satisfaction towards the private Not Supported \\
nursery. \\
$\mathbf{H}_{3}$ : There is a positive and significant relationship between \\
responsiveness and parents' satisfaction towards the Not Supported \\
private nursery. \\
$\mathbf{H}_{4}:$ There is a positive and significant relationship between \\
assurance and parents' satisfaction towards the private Supported \\
nursery. \\
$\mathbf{H}_{5}:$ There is a positive and significant relationship between \\
empathy and parents' satisfaction towards the private Supported \\
nursery.
\end{tabular}

\section{Discussion}

The four dimensions were examined on their influence on parents' satisfaction. The multiple regression analysis shows that parents' satisfaction is found to be highly influenced by tangibility. The result is in line with Kim's (2014) findings where tangibility is among the dimensions that contribute to customers' satisfaction level. Ismail, Ismail, Aziz, Aziz, Sharom, and Ramlan (2018) mentioned that parents place more concern on facilities when choosing a preschool for their children. Parents who focus more on the tangibles dimension do not just look at basic facilities. They also assess the private nursery based on the installation of safety equipment as well as cleanliness in the nursery. Security issues nowadays have captured parents' consideration to registering their child in a fully-equipped center.

The finding shows that there is a positive and significant relationship between reliability and responsiveness with parents' satisfaction. In the context of this study, parents display their consideration on the service provider's reaction-i.e. promptly and appropriately respond to the children's needs, emergency situation, notifying the guardian if the children get injured or sick, as well as demands and questions from parents. Parents expect the service providers to accurately record activities and notices as well as be proactive and responsible. Parents also expect the service provider to observe the arrival and departure time, vehicles that transport the children, to check the guardian at the time delivering the children and to communicate with parents. Snacks and meals can also be provided by parents themselves as children at 3 years old and below prefer to consume simple meals. 
Empathy is proven to have a significant and positive influence on parents' satisfaction. Parents observe empathy through the behavior of teachers - i.e. sufficient and satisfactory interactions between children and teachers, pay sufficient attention to every child, genuinely consider growth and development of children, and ability to well identify the individual personality and character of both children and parent.

Lastly, this study discovers assurance has a significant and positive influence on parents' satisfaction. Parents suppose the teachers to show the proper attitude when dealing with children, have a good character and treat children with kindness and gentility.

\section{Conclusion}

In conclusion, this study found that the tangibles dimension is the most influential factor that affects parents' satisfaction. This study has a few limitations that might affect its interpretation of the study findings. Firstly, the sample size was distributed to a few regions of Kuching only. Future researchers are recommended to include a broader geographic coverage to gather different views from the respondents. The use of a close-ended survey questionnaire might constraint the respondents to further express their opinions. Response biases might occur as some of the respondents do not read carefully on the questions and gave insincere respond merely based on their judgment. Future researchers are also recommended to compare parents' satisfaction towards private nursery across different cities to examine whether service quality of private nursery in different geographical areas is consistent and standardized.

\section{Acknowledgment}

This paper is funded by grant scheme F01/SpMYRA/1684/2018 and supported by the Universiti Malaysia Sarawak (UNIMAS).

\section{References}

AnghelM, G., Anghelache, C., Dumitrescu, D., BureaD., Stoica, R. (2018). Analysis of the Effect of Accessing the Community Funds for Financing Investments on Romania's Economic Growth, International Journal of Academic Research in Accounting, Finance and Management Sciences 8 (2): 102-112.

Arasli, H., Katircioglu, T. S., \& Mehtap-Smadi, S. (2005). A comparison of service quality in the banking industry. International Journal of Bank Marketing, 23(7), 508-526. https://doi.org/10.1108/02652320510629881

Arokiasamy, A. R. A., \& Tat, H. H. (2014). Assessing the Relationship between Service Quality and Customer Satisfaction in the Malaysian Automotive Insurance Industry. Middle-East Journal of Scientific Research, 20(227), 1023-1030.

Bailey, D. B. (1987). Collaborative Goal-setting with families: Resolving differences in values and priorities for services. Topics in Early Childhood Special Education, 7(2), 59-71.

Berry, L. L., Zeithaml, V. A., \& Parasuraman, A. (1990). Five Imperatives for Improving Service Quality. MIT Sloan Management Review, 31(4), 29.

Biernacki, P., \& Waldorf, D. (1981). Snowball sampling: Problems and techniques of chain referral sampling. Sociological Methods \& Research, 10(2), 141-163.

Bigne, J. E., Martinez, C., Miquel, M. J., \& Andreu, L. (2003). SERVQUAL reliability and validity in travel agencies. Annals of Tourism Research, 30(1), 258-262. 
INTERNATIONAL JOURNAL OF ACADEMIC RESEARCH ECONOMICS AND MANAGEMENT SCIENCES Vol. 8, No. 3, 2019, E-ISSN: 2226-3624 @ 2019 HRMARS

https://doi.org/10.1016/S0160-7383(02)00063-4

Coakes, S. J. \& Ong, C. (2011). SPSS: analysis without anguish: version 18 for Windows. Queensland: Wiley.

Cohen, L., Manion, L., \& Morrison, K. (2007). Research Methods in Education (6th Editio.). New York: Routledge Taylor \& Francis Group.

Doherty, G., Forer, B., Lero, D. S., Goelman, H., \& LaGrange, A. (2006). Predictors of quality in family child care. Early Childhood Research Quarterly, 21(3), 296-312. https://doi.org/10.1016/j.ecresq.2006.07.006

Friedman, B. A., Bobrowski, P. E., \& Markow, D. (2007). Predictors of parents' satisfaction with their children's school. Journal of Educational Administration, 45(3), 278-288. https://doi.org/10.1108/09578230710747811

Gibbons, S., \& Silva, O. (2011). School quality, child wellbeing and parents' satisfaction. Economics of Education Review, 30(2), 312-331.

Gronroos, C. (1984). A Service Quality Model and its Marketing Implications. Europiean Journal of Marketing, 18(4), 36-44. https://doi.org/10.1108/EUM0000000004784

Guesalaga, R., \& Pitta, D. (2014). The importance and formalization of service quality dimensions : a comparison of Chile and the USA. JOurnal of Consumer Marketing, 31(2), 145-151. https://doi.org/10.1108/JCM-08-2013-0660

Hair J. F., Black, W. C., Babin, B. J., \& Anderson, R. E. (2009). Multivariate Data Analysis (Seventh Ed.). https://doi.org/10.5829/idosi.mejsr.2014.20.09.12029 https://doi.org/10.5829/idosi.wasj.2013.21.12.657

Iram, U., \& Butt, S. M. (2004). Socioeconomic and environmental determinants of child-care patterns of preschoolers in Pakistan. International Journal of Social Economics, 31(3), 218238. https://doi.org/10.1108/03068290410518229

Ismail, F. L. M., Ismail, A., Aziz, A. M. A., Aziz, A. S. Sharom, N. Q., \& Ramlan, S. R. (2018). Service Quality of Public Preschool Education in Malaysia: Perceptions of Parents. Sains Insani, 3(2), $28-37$.

Jonsdottir, K., Bjornsdottir, A., \& Bæck, U. D. K. (2017). Influential factors behind parents' general satisfaction with compulsory schools in Iceland. Nordic Journal of Studies in Educational Policy, 3(2), 155-164.

Kassim, N. A., Baharuddin, K., Ishak, N. H., Ariff, N. Z. Z. M., \& Buyong, S. Z. (2018). Identifying the Importance of Types of Music Information among Music Students. International Journal of Academic Research in Progressive Education and Development, 7(1), 1-11.

Kim, E. J. (2014). Quality analysis of child care services using SERVQUAL and study on factors effecting intent to recommend to others and to re-use. Seoul, KR: Korea Institute for Health and Social Affairs.

Ladhari, R. (2009). Assessment of the psychometric properties of SERVQUAL in the Canadian banking industry. Journal of Financial Services Marketing, 14(1), 70-82. https://doi.org/10.1057/fsm.2009.2

Liu, W. P., Yeung, A. S., \& Farmer, S. (2001). What do parents want from day care services? Perspectives from Australia. Early Childhood Research Quarterly, 16(3), 385-393. https://doi.org/10.1016/S0885-2006 (01)00108-9 
INTERNATIONAL JOURNAL OF ACADEMIC RESEARCH ECONOMICS AND MANAGEMENT SCIENCES Vol. 8, No. 3, 2019, E-ISSN: 2226-3624 @ 2019 HRMARS

MANG'ELI, A. M. (2013). An Investigation into Service Quality Determinants and Their Effectiveness in Real Estate Agency in Nairobi.

McNaughton, D. (1994). Measuring parent satisfaction with early childhood Intervention programs : Current practice, problems and future perspectives. Topics in Early Childhood Special Education, 14(1), 26-48. https://doi.org/10.1177/027112149401400106

Ministry of Education Malaysia. 2013. Malaysia Education Blueprint 2013-2025 (Preschool to Post-Secondary Education).

Mustafa, L. M., Yunus, N. K. Y., \& Azman, M. N. A. (2014). An Overview of Private Preschool in Malaysia: Marketing Strategies and Challenges. Procedia-Social and Behavioral Sciences, 130, 105-113.

Olorunniwo, F., Hsu, M. K., \& Udo, G. J. (2006). Service quality, customer satisfaction, and behavioral intentions in the service factory. Journal of Services Marketing, 20(1), 59-72.

Pallant, J. (2013). SPSS survival manual. McGraw-Hill Education (UK).

Parasuraman, A., Zeithaml, V. A., \& Berry, L. L. (1985). A Conceptual Model of Service Quality and Its Implications for Future Research. Journal of Marketing, 49(4), 41-50. https://doi.org/10.1016/S0148-2963 (99)00084-3

Parasuraman, A., Zeithaml, V. A., \& Berry, L. L. (1988b). Servqual : A Multiple-Item Scale For Measuring Consumer Perc. Journal of Retailing, 64, 12.

Rust, R. T., \& Oliver, R. L. (1994). Service quality: New directions in theory and practice. California: Sage Publications.

Scheirer, M. A. (1978). Program participants' positive perceptions. Evaluation Quarterly, 2(I), 5370. Retrieved from http://journals.sagepub.com/doi/pdf/10.1177/0193841X7800200102

Spreng, R. A., \& Mackoy, R. D. (1996). An empirical examination of a model of perceived service quality and satisfaction. Journal of Retailing, 72(2), 201-214.

Suki, N. M. (2013). Examining the correlations of hotel service quality with tourists' satisfaction. World Applied Sciences Journal, 21(12), 1816-1820.

Tabachnick, B. G., \& Fidell., L. S. (2001). Using multivariate statistics (Fourth Edi.). Boston, MA: Allyn \& Bacon.

Tavakol, M., Dennick, R. (2011). Making Sense of Cronbach's Alpha. International Journal of Medical Education. 2, 53-55 Editorial

Upshur, C. C. (1991). Mothers' and fathers' ratings of the benefits of early intervention services. Journal of Early Intervention, 15(4), 345-357.

Virtanen, A., \& Runtti, S. (2015). Parents' satisfaction on the quality of education and care in Qatar-Finland International School. University of Jyvaskyla.

Wang, Y., Lo, H., \& Yang, Y. (2004). An integrated framework for service quality, customer value, satisfaction: Evidence from China's telecommunication industry. Information Systems Frontiers, 6(4), 325-340.

Zikmund, W., Babin, B., Carr, J., \& Griffin, M. (2013). Business research methods. (9thed,).Cengage Learning. 